\title{
As múltiplas assinaturas do Estado: práticas do município-réu nos processos de (des)habitação no Rio de Janeiro
}

The multiples signatures from the State: practices of a culprit municipality in the process of (un)occupying Rio de Janeiro

\section{Anelise Gutterres}

\section{(2) OpenEdition Journals}

Edição electrónica

URL: https://journals.openedition.org/aa/2259

DOI: 10.4000/aa.2259

ISSN: 2357-738X

\section{Editora}

Programa de Pós-Graduação em Antropologia Social (UnB)

\section{Edição impressa}

Data de publição: 1 dezembro 2017

Paginação: 207-238

ISSN: 0102-4302

\section{Refêrencia eletrónica}

Anelise Gutterres, «As múltiplas assinaturas do Estado: práticas do município-réu nos processos de (des)habitação no Rio de Janeiro», Anuário Antropológico [Online], v.42 n.2 | 2017, posto online no dia 12 junho 2018, consultado o 18 maio 2021. URL: http://journals.openedition.org/aa/2259 ; DOI: https://doi.org/10.4000/aa.2259

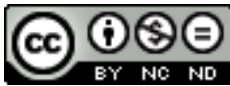

Anuário Antropológico is licensed under a Creative Commons Atribuição-Uso Não-Comercial-Proibição de realização de Obras Derivadas 4.0 International. 


\title{
As múltiplas assinaturas do Estado: práticas do município-réu nos processos de (des)habitação no Rio de Janeiro ${ }^{1}$
}

\author{
Anelise Gutterres \\ Museu Nacional/UFRGS
}

Neste artigo, compartilho algumas reflexôes elaboradas em minha pesquisa de pós-doutorado a partir de um trabalho de campo realizado na sede do Núcleo de Terras e Habitação (NUTH) da Defensoria Pública do Estado do Rio de Janeiro (DPGERJ) durante aproximadamente seis meses de 2016. ${ }^{2}$ Entre as razóes que motivam uma pesquisa nos arquivos do NUTH está o término dos Jogos Olímpicos no Rio de Janeiro, em agosto de 2016, que configura o que foi chamado - por jornalistas e também por colegas que atuam em movimentos sociais, organizações não governamentais ou, como eu, em pesquisas acadêmicas - de "o fim da era dos megaeventos" na capital fluminense. ${ }^{3}$ A expressão se refere ao término do período, de aproximadamente quinze anos, que se inicia com a escolha e divulgação do Rio de Janeiro como sede de grandes eventos esportivos uma "era" que incluiria os Jogos Pan-americanos, anunciados em 2002 e realizados em 2007 no Rio de Janeiro; a Copa do Mundo, cuja escolha do país sede fora divulgada em 2007, para realização em 2014, no Rio de Janeiro e em mais 11 cidades brasileiras; e, finalmente, os Jogos Olímpicos e Paralímpicos, que foram divulgados em um grande evento na praia de Copacabana em 2009 e realizados entre agosto e setembro de 2016, também na cidade do Rio de Janeiro. ${ }^{4}$

A observância de uma "era dos megaeventos" e o efeito dela na contençáo e/ ou remoção da populaçáo pobre na cidade, portanto, me motiva a construir um projeto de pesquisa que se debruce sobre os arquivos e documentos do Núcleo. É importante ressaltar que os defensores e as defensoras ${ }^{5}$ que integraram o NUTH durante grande parte dessa "era" mostravam-se solidários aos grupos de familiares e moradores dos territórios em ameaça de remoçáo, participando de eventos e encontros nas localidades "atingidas". ${ }^{6}$ As açóes civis públicas (ACPs) ${ }^{7}$ elaboradas neste período, que tinham o município como réu, buscavam reverter o quadro das remoçóes de moradia na cidade durante o período de preparação para os eventos. Como os Processos $^{8}$ são, na maioria das vezes, longos, muitos dos moradores foram assistidos por diferentes defensores e defensoras, bem como distintos grupos de estagiárias e estagiários no interior da defensoria. 
É preciso destacar que atualmente, e particularmente em relação a outros estados, o NUTH tem a confiança daqueles que o procuram. Durante os anos a que se dedica a pesquisa, todavia, houve ciclos mais obscuros. ${ }^{9}$ Durante o ano de 2011 (e 2013, porém, com menos impacto), vimos os objetivos e a orientaçáo desse núcleo ficarem à sombra do governo municipal, o que acarretou rupturas, demissóes e um pedido de exoneração. Uma das etapas que integra a produção do Processo de assistência jurídica é a realização de reunióes com os moradores, onde eles são atendidos pelos defensores e defensoras e relatam o ocorrido nas entranhas de seu cotidiano, sua vivência entre jogos e estratégias dos poderes atuantes na regiáo. Durante esses dois anos - em que o Núcleo teve sua autonomia controlada através de um arranjo político que interferiu na composição e atuação do quadro de defensores -, os moradores ficaram desconfiados de participar desses atendimentos, com receio de sofrer retaliaçóes daqueles que promoviam ou participavam das práticas de poder, ${ }^{10}$ muitos deles integrantes da equipe técnica da prefeitura, ou mesmo moradores da favela que trabalhavam aliados à perspectiva do município. $\mathrm{Na}$ falta de espaços de diálogo no interior da institucionalidade, não faltaram reivindicaçóes dos moradores e militantes da causa da moradia exigindo a retomada da autonomia e da "integridade" da defensoria pública, o que, para esses atores, acabou acontecendo em 2015. O momento em que realizei a pesquisa é, portanto, um movimento entre ciclos, em que os moradores e militantes observam com positividade a pessoalidade com que defensores atuam ${ }^{11}$ na administração burocrática, fazendo questão de conhecer os locais de moradia dos atendidos e prestando, quando possível, assistência nos próprios territórios de conflito.

Além desses ciclos, outro fato me instiga a olhar com mais cuidado para o lado de lá do balcão ${ }^{12}$ - ou seja, mergulhar nos documentos produzidos pelos Processos. Empiricamente, nota-se que o ínterim de 2007 a 2016 foi caracterizado por uma dinâmica de tensão e conflito na propalação de programas de urbanização e/ ou produçáo de moradias de interesse social por agentes do município do Rio de Janeiro, especialmente na implementação do Programa Morar Carioca; do Programa de Aceleração de Crescimento (PAC); e do Programa Minha Casa Minha Vida em favelas e localidades: (1) próximas às áreas que sediam os megaeventos; (2) em favelas "pacificadas", escolhidas para receber obras vultuosas (em cifras e tamanho), geralmente associadas, nos discursos políticos, à retomada da cidadania e segurança nestes locais. Busquei, portanto, refletir sobre estas "formas de intervenção social definidas como políticas públicas" (Souza Lima, 2002:13) em suas dobras. Propus olhar para estes programas ligados à habitaçáo, racionalizados em planos escritos pelos governos durante o período estudado, ${ }^{13}$ 
através de determinados contextos de sua gestão, mas também na forma como foram geridos como soluções para "problemas sociais e urbanos".

De acordo com Souza Lima (2002:16), gestar e gerir são "duas dimensóes decupáveis da mesma operaçáo e nos permitem recortar e descrever nuances nos exercícios de poder". Enquanto gestar nos aponta para "uma função constitutiva e pedagógica” que está imbuída pelo "desejo do bem”, perceptível na tutela de "segmentos concebidos como constitutivamente despossuídos das condições mínimas para a vida social em pé de desigualdade”, gerir nos sinalizaria "ao controle cotidiano de uma administração que é perpassada por interesses pessoais e de redes de clientelas" e que representa este "tutor de coletivos, controlador de espaços, mantenedor dos desiguais em seus nichos". Estar atenta a estas duas dimensôes, que também são produtoras do contexto pesquisado, apontaria para a relação forte "entre domínio de terras e fluxos sociais a partir do controle de segmentos da populaçáo", tal como sugerido por Souza Lima.

$\mathrm{Na}$ análise das motivaçóes das ACPs, mesmo guiada pela hipótese de que havia recorrências que uniam essas açóes, busquei olhar também para as particularidades de cada Processo. No âmbito das recorrências, observei como a comunicação entre os defensores e as defensoras do NUTH neste período - com secretarias, departamentos, institutos, peritos, apoiadores, técnicos, especialistas, pesquisadores -, principalmente através de ofícios, foi produzindo uma rede de instituiçóes, grupos e documentos que acabaram desenhando a gestão do Estado nesses territórios.

Do lado de cá do balcão, eu estava baseada na experiência da pesquisa realizada para o meu doutorado, onde acompanhei a formação de algumas redes de contestação às obras dos "megaeventos" e as recorrências da governamentalidade na gestão da habitação dos pobres em diferentes localidades do país durante o período de preparaçáo para tais eventos. ${ }^{14}$ Formado em 2009, um dos coletivos que acompanhei e de que participei - o Fórum Comunitário do Porto, composto de movimentos sociais, pesquisadores-apoiadores, ONGs e militantes da moradia de interesse social - teve papel importante no incentivo aos moradores e moradoras para que buscassem assistência judicial no NUTH, já que vivenciou com eles a ampliação do cenário de ilegalidades decorrente da atuação dos agentes vinculados, formalmente ou não, à Secretaria Municipal de Habitação na região. Em meados de 2011, quando a comissão de moradores ${ }^{15}$ do Morro da Providência ingressou formalmente com pedido de assistência - e em seguida, já assistida pelo NUTH, em uma ACP contra o município do Rio de Janeiro -, diversos outros grupos de moradores (em diferentes favelas, comunidades, cortiços na regiáo central e nas zonas norte e oeste da cidade) já tinham assistência e açóes agravando a prefeitura 
por ilegalidades e violências similares às que viveram os moradores da Providência. As recorrentes ilegalidades cometidas pela prefeitura do Rio de Janeiro foram tema de trabalhos acadêmicos (Faulhaber, 2012; Fernandes, 2013; Magalhães, 2013) e de relatórios produzidos por coletivos civis organizados (Comitê Popular Rio da Copa e Olimpíadas, 2011, 2012) ou por jornalistas, correspondentes de veículos de mídia internacional e nacional.

Em termos metodológicos, a pesquisa aqui apresentada segue a provocação de Souza Lima (2002:11), unindo fontes impressas à observação etnográfica. Aproveito para fazer referência a etnografias realizadas em instituiçóes estatais ou entre e a partir de documentos e Processos, que foram (e são) fundamentais na construção das reflexôes e descrições aqui apresentadas. Destaco o trabalho de Lugones (2009) sobre os tribunais de menores em Córdoba; o de Schuch (2009) na Fundação de Atendimento Socioeducativo em Porto Alegre; o de Claudia Fonseca $(1997,2004)$, que analisou documentos dos processos de disputa pela guarda de crianças no início do século XX e também de investigação da paternidade em diferentes instâncias jurídicas de Porto Alegre; a pesquisa de Adriana Vianna (1999) nos registros policiais que classificam determinada população infantojuvenil no início do século XX; e o de Sousa Lima (1995) sobre o poder tutelar como exercício de poder de determinados aparelhos de governo. Mais recentemente, o artigo escrito por Lowenkron e Ferreira (2014) traça um imprescindível panorama das pesquisas relativas a essa temática.

Tal como preconiza Veena Das (2004:240), as vidas em geral são permeadas por documentos. A forma da nossa existência, onde podemos ou náo podemos circular, é demarcada por papéis que encadeiam certos processos. Certa da importância de pesquisar documentos, e buscando um diálogo mais denso com a já extensa bibliografia e as abordagens sobre o tema, destaco o trabalho de Mariza Peirano (1986), que, em diálogo com Wanderley Guilherme dos Santos, reflete sobre a relevância de determinados documentos na construção da cidadania e no acesso aos direitos civis, políticos e sociais no Brasil. Trazendo como exemplos a carteira de trabalho e o título de eleitor, a autora mostra que, tal como revelado por Santos, a cidadania no Brasil se desenvolveu "através de um sistema de estratificação ocupacional”, ou seja, esteve relacionada ao reconhecimento, à definiçáo e à inclusão de determinadas profissóes e ofícios e dos direitos associados a elas.

O ponto que nos interessa nesse debate trazido por Peirano é o caráter simbólico que os documentos assumem no Brasil neste período e que seguem incorporados nas práticas institucionais, integrados à dinâmica de acesso aos direitos no país. $\mathrm{Na}$ discussão proposta pela autora, estes documentos seriam símbolos de identidade cívica, fornecidos por órgãos públicos, e sua obtenção exigiria "determinados 
requisitos estipulados por lei", o que marcaria principalmente as camadas pobres, já que seria utilizado como quesito de diferenciação e distinção entre o "cidadão" e o "marginal". No caso de nossa pesquisa, vimos que a posse de determinados documentos era constantemente assinalada por defensores e defensoras. Eram elementos constantes e imprescindíveis para a montagem das açóes, já que tinham a função de comprovação formal da existência do objeto e da veracidade das razóes do Processo. Entre os documentos principais do Processo que asseguravam a atuação da Defensoria Pública, estava o atestado de hipossuficiência, ${ }^{16}$ geralmente realizado por autodeclaração, preenchido e assinado pelo "assistido". Inicialmente, também era anexado ao Processo algum comprovante de residência - e, para tal, era aceita uma gama muito variada de documentos, como notas fiscais de materiais de construção, atestado de frequência dos filhos na escola ou prontuários médicos -, uma cópia da carteira de identidade e, algumas vezes, fotografias do local de moradia (mostrando ou não a ação ilegal do município).

A entrega desse conjunto de documentos habilitava o morador ameaçado de remoção à categoria de assistido. A partir desse momento, o simbolismo dos documentos, tal qual nos fala Peirano, ganhava importância cotidiana, já que as famílias e/ou os sujeitos assistidos começavam também a vivenciar uma lógica de recolhimento e guarda de papéis que julgavam ser potenciais provas da autenticidade de suas declaraçôes, capazes de materializar a violência à qual estavam expostos. Após, ou mesmo no momento de produção do Termo de Declaração, era recorrente, portanto, que os assistidos e as assistidas ${ }^{17}$ passassem a oferecer papéis aos defensores e defensoras, certos de que sua quantidade auxiliaria na comprovação da ação nebulosa dos agentes do município, tal como relatado nos sucessivos atendimentos que ora acompanhei, ora tive acesso pela leitura dos Termos de Declaração.

O Termo, como veremos, é o espaço onde se descreve a opacidade das açóes do município na localidade. $\mathrm{O}$ ato de declarar e de registrar a declaração pareceu um esforço de resgate e manutenção da dignidade ${ }^{18}$ que teria sido tolhida pela atuação de agentes ligados à municipalidade. Esse ato era, também, uma tentativa de tornar visível - diante de atuaçóes fabricadas pelos agentes para ser intangíveis - um emaranhado de atores e práticas produzidas pelo município-réu no intuito de remover as moradias. Pensando nesse emaranhado de atores e práticas, sigo aqui as pistas de Vianna (2014a), que, ao relatar os desafios da pesquisa em Processos e documentos, ressalta a questáo do tempo nas vidas por eles relatadas: as idas e vindas a uma unidade administrativa a fim de regularizar uma situação, os retornos, a espera, as averiguaçóes, "ou simplesmente carimbos e protocolos que consagram o adiamento de audiências" em Processos sobre o assassinato "de 
um filho, irmão ou marido", ou, no nosso caso, sobre a perda de uma moradia ou a ameaça de perdê-la.

Tratando de um conjunto híbrido de documentos que compóe os Processos judiciais como "artefatos paradigmáticos das práticas do conhecimento moderno" (Ferreira, 2013, 2015; Riles, 2006), nosso objetivo é, por um lado, refletir sobre seu simbolismo como percurso de produção de uma luta por reconhecimento, que passa pela manutenção da dignidade; e, por outro lado, compreender melhor as estratégias produzidas pelo Estado na gestão da habitação em áreas de favelas e periferias na "era dos megaeventos" - tanto as estratégias utilizadas pelo municípioréu quanto aquelas que refletem nas açóes do NUTH, com foco nos sensos e mecanismos judiciais manejados nos documentos que integram os Processos analisados. Sobre os processos de gestão, destacamos novamente o pensamento de Souza Lima (2002:11), que os descreve como processos que englobam a produçáo de saberes, práticas de aparelhos de governo, "o controle da mobilidade espacial de segmentos da populaçáo (índios, menores, migrantes, favelados)” e práticas de espetacularização da vida política.

Feita essa pequena introdução de enredos que nutrem nossa pesquisa - e movem a escrita deste artigo -, buscarei costurar diferentes situaçóes, em um conjunto também muito híbrido de dados, narrativas e momentos. Entre eles, relatos de experiências vividas durante o período do doutorado e reflexóes oriundas de minha pesquisa no NUTH. Aqui acompanharemos, portanto, situaçóes onde são notáveis múltiplas assinaturas, em locais e Processos judiciais diferentes. Nossa intenção não é reconstruir linearmente as etapas dos Processos; trabalharemos com os trechos que enfatizam as marcas daquilo que estamos chamando de processo de des(habitação) de populações de seus territórios de moradia e circulação.

Adotamos uma orientação de confidencialidade na construção dos casos no que se refere ao corpo de funcionários e estagiários do Núcleo. Seguindo o proposto por Ferreira (2015:29), o acesso aos registros documentais aqui expostos está atrelado a um interesse específico da pesquisa e uma censura determinada pelas normas da escrita acadêmica, atenta à segurança dos interlocutores. Em seu trabalho, Veena Das (2004:235) destaca que não é precisa em fornecer datas e locais; assim como a autora, modificamos os nomes dos participantes deste estudo a fim de garantir seu anonimato e sua integridade. Tal como destaca Vianna (2014a) e é retomado de forma sensível pelo trabalho de Ferreira (2015), é necessário estar atenta às lacunas, àquilo que não é passível de apreensão a partir dos depoimentos ("mas o que as pessoas disseram efetivamente?") nos registros burocráticos da queixa ("mas como se deu a interaçáo com o funcionário?”) e nos campos preenchidos nos formulários ("como se deram os jogos relacionais entre entrevistador e entrevistado que podem 
ter contribuído de maneira significativa para essa resposta?”). As questões ressaltadas por Vianna são norteadoras tanto dos limites e das características metodológicas da pesquisa em arquivos quanto da necessidade de vigilância e questionamento constante que o trabalho com tal material evoca.

\section{Assinaturas da (des)habitação}

Na zona portuária do Rio de Janeiro, em especial no Morro da Providência, uma das localidades em que realizei o trabalho de campo durante o doutorado, as ameaças de remoção e as incursóes sistemáticas de agentes ligados à prefeitura tinham como objetivo aterrorizar moradoras e moradores utilizando o paliativo assistencial do aluguel social como política habitacional de médio prazo. $\mathrm{O}$ controle do tempo era um dos efeitos da gestão da habitação e, nessa ocasião, a utilização do adjetivo "urgência" foi comum para enfatizar a necessidade de saída das moradoras de suas casas. A "urgência da obra” era propalada com ameaças que foram sentidas como terror, já que forçavam as famílias a decidir em poucos dias, ou mesmo ali, na presença do funcionário, o que fazer. As opçóes oferecidas pelos funcionários à moradia - que, nas palavras dos agentes públicos da prefeitura, eram consideradas "alternativas"19 - eram explicadas parcialmente, e algumas inclusive eram omitidas a fim de tornar mais atraente a opção preferida dos agentes. Muito raramente essas alternativas incluíam a permanência em local onde a obra era ou seria realizada, ou mesmo na própria casa, com uma possibilidade de revisão da intervenção planejada para a área.

Nessa dinâmica de resistências, tensão e desconfiança, algumas famílias não resistiram e acabaram saindo de suas casas. ${ }^{20}$ Ficou evidente nesses casos a produçáo concomitante de escombros em torno das moradias que tinham passado pela "descaracterização", ${ }^{21}$ ao mesmo tempo em que obras de mobilidade, saneamento e urbanização eram executadas nesses locais. Os moradores olhavam para esses entulhos em torno de suas casas e reconheciam que estavam em um cenário de guerra (Gutterres, 2016). Eram famílias altamente desgastadas pelo obscurantismo da ação do munícipio, que as ameaçava, produzia documentos falsos para coagi-las a deixar suas moradias, propagava rumores, descaracterizava os becos onde viviam, suas casas e as de seus vizinhos. Há, no entanto, diversas outras práticas recorrentes nas açóes da prefeitura. Não é nosso objetivo, nem penso que seja possível, listar e classificar todas elas neste artigo, já que são práticas que se reatualizam e se reinventam. Interessa-nos observá-las e analisá-las - já que elas interligam Processos judiciais de moradores de diferentes lugares - a fim de refletir sobre a existência de uma razão governamental no tratamento desses territórios e identificar as formas dessas práticas neste período. 
Estamos compreendendo aqui o Estado em seus múltiplos aspectos, em suas múltiplas "assinaturas", como propóe Veena Das (2007:226): a entidade racional presente na estrutura das regras e regulaçóes incorporadas na lei e nas instituiçôes que as implementam; e a forma mágica como as práticas do Estado figuram, principalmente em favelas e periferias, através de rumores, representação mimética, obscuridade e poder. Conforme destaca Lopes (2016:12), falar de Estado sob esta perspectiva "é tratar de formas contínuas de estabelecimento de poder, de hierarquia e de dominação, sem, com isso, entender que tais formas são fixas, estabelecidas em uma única direção e/ou intransponíveis". Indicando uma perspectiva similar à de Veena Das na compreensão dos processos de formação do Estado, aproximamo-nos de Castilho, Souza Lima e Teixeira (2014:22), autores que compreendem a potência de uma etnografia das práticas de poder a fim de "apreender como se faz Estado", ou seja, a partir de uma "ênfase à dimensão performativa e à ação simbólica na produção de efeitos (e afetos) de poder, e como nós, antropólogos, participamos desse fazer”. Seguindo tal orientação teórica e analisando a data dos primeiros atendimentos e os Termos de Declaração recebidos pelo NUTH, construí um mapeamento do que chamarei de "assinaturas" do Estado na gestão da moradia em territórios de favela e periferias do Rio de Janeiro nesta última década. A montagem deste panorama visa averiguar a abrangência das práticas de remoção como esforço de des(habitação) desta população e, consequentemente, de produção de territórios de vulnerabilidade.

Tal como sugerido no trabalho de Machado e Figueiredo (1981) nos anos 1980 - onde ressaltam que a reivindicação da urbanização em determinadas áreas, como as das favelas cariocas, não suprimia as remoçôes e, ao contrário, poderia ser utilizada para justificá-la -, vimos os programas de urbanização propostos nesse período com cautela. Nossa pesquisa mostrou a relevância da previsão dos autores, já que muitos dos programas de urbanização propalados utilizaram a necessidade e o desejo de urbanização por parte dos moradores - leia-se, saneamento básico, iluminação, arruamento, acessibilidade - para efetivar a remoçâo parcial ou total das moradias em diferentes localidades. Por essa razão, é necessário dizer que entendemos a "urbanização" como uma categoria em disputa, ao passo que "remoção" seria uma categoria de luta - geralmente empregada pelos movimentos sociais ou moradores ligados a eles para dar visibilidade às açóes de esbulho e turbação de posse, promovidas pela prefeitura municipal em moradias de favelas da cidade no ínterim destes eventos. Observamos essas categorias em diálogo com a noção de "palavra-ato", utilizada por Vianna (2014b:210) em sua pesquisa no movimento de mães e familiares vítimas de violência policial no Rio de Janeiro. Conforme a autora, as palavras são usadas para narrar articulaçốes "que podem 
funcionar como instrumentos de acusação, de compreensão, de solidariedade e de luto, reconstruindo-se social e subjetivamente" no processo em que sáo construídas. Entendo a expressão "remoção", portanto, como uma palavra-ato, já que compóe o léxico dos militantes e ativistas em defesa da moradia, mobilizando sentidos estratégicos em falas e ações públicas.

A partir da leitura dos Termos de Declaração, notamos que as "declarantes" narram a "chegada" dos programas de urbanização a partir da "visita" de funcionários da prefeitura em suas casas, relatando um ambiente de incertezas, intensificadas posteriormente pela difusão de rumores. Realizadas por técnicos e agentes do município ligados a setores responsáveis pela habitação, essas incursóes explicitam práticas específicas - baseadas na irradiação da dúvida entre as moradoras e os moradores - e têm como objetivo a intimidaçáo e a coação destas habitantes para que se desloquem de seus locais de moradia, oferecendo como contrapartida uma solução vinculada aos programas de habitação e urbanização já citados. A declaraçáo - realizada individualmente por moradoras e moradores integrantes de pequenos coletivos e comissóes e, como já ressaltamos, oriundas de favelas da cidade do Rio de Janeiro - é uma das primeiras etapas da assistência prestada pelo Núcleo. Se por um lado há a obscuridade e a desinformação como práticas do município na manutenção da vulnerabilidade dos habitantes nestes territórios, por outro, como veremos, uma das tarefas de defensoras e defensores é acessar oficialmente as secretarias e os órgãos municipais em busca de informaçóes.

A decisão de imbricar-se em um Processo judicial que tem a prefeitura como ré é uma tarefa dura e arriscada para quem vive em áreas onde a gestão diferencial dos ilegalismos é materializada em operações policiais e ações de ordenamento. É uma decisão difícil porque pode haver represálias, constrangimentos, coações, conflitos com vizinhos, já que por causa dos Processos, os assistidos são enquadrados por agentes do poder público - que frequentemente utilizam o aparato midiático como assessoria de imprensa - como "aqueles que são contra o progresso". E é arriscada porque, nesta gestão diferenciada dos ilegalismos - destacada por Foucault $(2004)^{22}$ tendo em vista a contenção dos ilegalismos populares ao longo dos séculos -, os moradores ficam ainda mais suscetíveis às penalizaçóes, sejam formais (apreensão de mercadoria de vendedores ambulantes, detençôes), sejam ilegais ("acertos", "achaques", ${ }^{23}$ terror psicológico).

Os grupos que entram com a ação são, portanto, uma pequena parcela dos moradores e habitantes de áreas que passam por conflitos fundiários ou que vêm sendo classificadas nos últimos anos como zonas degradadas, vazias, áreas com habitação precária, que por essa razão são foco de intervenção estatal específica. Sobre a decisão de entrar ou não com uma ação, destaco a noção de "tempo 
da tutela" trazida por Lucas Freire (2015:81) em sua pesquisa no Nudiversis. Segundo o autor, há uma série de disciplinamentos, "peregrinações burocráticas e os procedimentos de assistência” que coloca o assistido em um longo estado de liminaridade. Se, por um lado, o município-réu atua através das ameaças no controle do tempo dos moradores e moradoras de favelas e periferias, por outro, há um controle do tempo, ou o efeito do tempo da tutela, seja através da expectativa de um desfecho positivo, seja pela prática das reatualizaçóes e acompanhamentos no andamento do Processo, ao tornar-se assistido do Núcleo. Nem todos os moradores estavam dispostos a vivê-lo.

\section{Oficiando}

O rastreio - nas coordenadorias e nos setores vinculados e responsáveis pelas ações de urbanização nesses locais - é realizado através da emissão dos ofícios. A análise desta comunicação - entre a defensoria e estes diversos setores - vem evidenciando algumas temporalidades da burocracia, construídas entre os carimbos e as rubricas de saída e chegada dos documentos. Conforme já ressaltado, os ofícios constavam no material das pastas e, também, como argumento e comprovação dos pedidos de esclarecimento ou informação ${ }^{24}$ no conteúdo das ações.

Uma das primeiras pastas que analisei continha documentos referentes à localidade conhecida como Estradão, na zona oeste da cidade. As pastas eram quase sempre azuis e continham o nome da comunidade na capa e uma numeração de referência na lombada. As pastas da comunidade do Estradão estavam divididas por intervenção, já que produziram Processos diferentes. A primeira pasta era relativa a "intervençóes urbanísticas e processo de regularização fundiária na área do Setor 1" da comunidade, executadas pela União Federal. A segunda continha as "intervençóes urbanísticas do Projeto Morar Carioca, realizadas pela Prefeitura no Setor 2". E a terceira tratava das "obras do Corredor Viário da TransOlímpica", também em execução pela Prefeitura. A amplitude da área e as intervençóes e instituiçóes envolvidas em cada parcela do território levaram ao desmembramento do Processo em três setores.

No caso da comunidade do Estradáo, verifiquei que o primeiro ofício foi emitido pelo NUTH, com data de 24 de maio, ou seja, dias após o primeiro atendimento. Destinado ao secretário de Habitação do Município e com caráter de máxima urgência, nele os defensores declaram que os moradores procuraram o NUTH relatando preocupação com a situação da comunidade, visto que a intervenção urbanística Morar Carioca teria iniciado na regiáo sem que fosse apresentada e debatida com eles a forma de execuçáo do projeto e seus impactos. Ao finalizar o texto, os defensores alegam que essa não é a primeira vez que o 
Núcleo oficia a Secretaria de Habitação do Município (SMH) sobre o projeto sem, todavia, receber uma resposta.

Um ofício idêntico é enviado ao subprefeito da regional da Barra da Tijuca, no mesmo dia. Em 27 de maio, o mesmo defensor público solicita ao secretário de Habitaçáo quatro documentos - estudo de impacto de vizinhança, de impacto ambiental, o relatório destes estudos e as atas de audiência pública da implementação do Morar Carioca na região - solicitando uma cópia dos Processos administrativos, caso existam. Esse mesmo texto é enviado ao secretário Municipal de Obras. Sem receber respostas e tampouco cópia dos documentos solicitados, em 9 de julho o defensor reitera o pedido de informaçôes em novo ofício ao secretário de Habitação, pedido replicado ao subprefeito. Em 10 de julho, reitera novamente o ofício e solicita que o secretário de Obras responda. Em 15 de julho, a Secretaria Municipal de Obras envia ofício dizendo que já respondera à solicitação em 4 de junho. Reforça, todavia, que o NUTH deve enviar o documento para a SMH, que seria a responsável pelo Morar Carioca e que o assunto em tela não está inserido no rol de atribuiçóes da SMO. Náo encontrei na pasta uma resposta da Secretaria Municipal de Habitação aos pedidos dos defensores.

Em 5 de agosto, os defensores enviam um novo ofício, dessa vez ressaltando que, em uma reuniáo realizada em 17 de julho na $\mathrm{SMH}$, na qual participaram os moradores integrantes da comissão que acompanha as açóes da prefeitura na região do Estradão, foram mostrados apenas slides e que neles náo se explicitava a área de intervençáo e o número de famílias atingidas, ou que poderiam ser reassentadas com o início das obras. Os defensores solicitam por ofício o que a comissão solicitara pessoalmente na reunião: todas as intervençóes previstas, seus locais, número de famílias atingidas, formas de reassentamento oferecidas. Sem resposta nenhuma, em outubro um novo ofício reitera o último pedido, solicitando um prazo de 10 dias para resposta da secretaria.

Em minha pesquisa na pasta, encontro um ofício de setembro de 2013 onde a SMH alega que, "pelos esclarecimentos prestados pela Coordenadoria de Inclusão Social da SMH”, pode somente informar que a última atua na área através do PAC e do Pró-Moradia ${ }^{25}$ na regiáo do Estradão, "realizando urbanizaçáo, infraestrutura, e produçáo habitacional", e que a equipe do trabalho técnico social da Coordenadoria "age conforme normativas e diretrizes do Ministério das Cidades e da Caixa Econômica Federal”. Na sequência do documento, o secretário informa que, "objetivando a promoção da participação popular nos projetos em curso na tentativa de garantir o acesso as informaçóes"26, a secretaria "vem realizando assembleias, reunióes e fórum" onde apresenta os projetos de obras e social, mantendo uma equipe na regiāo, que realiza atendimentos de segunda-feira 
a sexta-feira. Em anexo a este ofício, há fotos de um evento na comunidade e de uma placa no local onde se lê "Estradão em ação" junto a diversas imagens de obras que estão sendo realizadas na comunidade. Acima, entre os logotipos da prefeitura, lê-se Prefeitura Municipal do Rio de Janeiro, seguida de Secretaria Municipal de Habitação, logo abaixo Coordenadoria de Inclusão Social e, por último, Gerência de Assessoria de Integração.

Como já destacamos, as comunicaçóes entre ofícios são uma maneira de delinear quais instituições estão envolvidas na gestão da habitação, quais responsabilidades são atribuídas a elas e quais responsabilidades a instituição e seus técnicos se autoatribuem. A morosidade nas respostas, assim como a urgência em obtê-las, caracteriza a dinâmica da relação entre as partes e suas temporalidades burocráticas, já que se repete em outros Processos. É interessante notar qual setor da Secretaria de Habitação responde ao pedido dos defensores, que é a Coordenadoria de Inclusão Social. Sua resposta sugere que não há qualquer problema ou falta de informação no trabalho realizado na localidade, ressaltando ainda as boas práticas da participação popular, o livre acesso à informação e o modo como essas práticas estavam sendo seguidas nas reunióes pelas equipes responsáveis pelo Estradão em ação. São notáveis, neste caso, aspectos do que Castilho, Souza Lima e Teixeira (2014:13) descrevem sobre os processos de formação do Estado: "a produção da crença na unicidade, na coerência e na efetividade das práticas de poder da administração pública é um trabalho cotidiano" - por estarem envolvidos na crença da coerência e efetividade das práticas de poder da administração do munícipio para os moradores contestar judicialmente também era reconhecer a plasticidade e a violência desta produção. Se a "(re)produção ideológica faz Estado", como ressaltam os autores, ela o faz produzindo "subjetividades e assujeitamentos, agenciamentos, códigos de conduta e moralidades".

\section{Identificando assinaturas:}

\section{visitas, alternativas, inatividade e poder de império}

No curso da pesquisa, demorei um pouco para compreender que o conteúdo das pastas era muito mais vasto e variado do que os parágrafos contidos no Processo. Havia, portanto, uma necessidade de mediação e tradução do material reunido nas pastas à norma jurídica, com suas temporalidades, doutrinas e inclusive limitação de seus operadores e juízes. Notei que ela era fundamental ao trabalho dos defensores públicos, dos servidores públicos e estagiários e tinha como efeito, no caso do NUTH, o reforço do compromisso ético e político com aqueles e aquelas que atendem. 
$\mathrm{Na}$ reescrita dos Termos e na descrição de partes do Processo, busquei me transportar para a pequena sala onde geralmente são realizados os primeiros atendimentos e para as salas dos defensores onde são redigidas as açóes. Procurei restituir o momento em que, no interior desses espaços, estiveram os declarantes, sentados cada um em uma cadeira, diante de uma mesa com computador e uma servidora que as escutava enquanto digitava seus relatos no teclado. Na mesa ao lado, certamente estariam outros servidores e estagiários atendendo outras pessoas e produzindo conjuntamente novos Termos. A escuta do servidor, como mencionei no decorrer do texto, é qualificada e está presente na materialidade do Termo, que, por sua vez, é o material de origem das açóes elaboradas conjuntamente pelos defensores. A experiência de ambos no atendimento de diversos casos similares naquele período é aparente, principalmente nos trechos que nominei como parágrafos-nota - que é quando esse funcionário acrescenta ao Termo informações que já possui sobre o Processo e seu histórico, com a intenção de contextualizar posteriormente ao defensor o que pode ser relevante para "os fatos" do Processo.

Contendo três páginas, o termo de primeiro atendimento da pasta relativa ao setor dois da comunidade do Estradáo foi realizado em 2013 por uma servidora pública cujo nome aparece no final do documento, acima de seu número de matrícula. Nele, três pessoas, duas mulheres e um homem, são consideradas "declarantes". Seus nomes constam no topo da página, seguidos de nacionalidade, estado civil, ocupação, inscrição no $\mathrm{CPF}$, residência, domicílio e telefone.

$\mathrm{Na}$ parte chamada de "Informaçôes sobre a ocupação", vemos que uma das declarantes afirma que reside na comunidade desde 1997. Sabemos que ela se lembra bem deste ano, porque entre parênteses a servidora escreve "(ano do seu casamento)". Seu marido, que hoje tem 40 anos, "nasceu e foi criado no local". A segunda declarante afirma que nasceu ali, já que sua avó é funcionária de um antigo hospital que ainda está em operação na área, e trabalha lá há quarenta anos. Ela faz questão de incluir no Termo que reside há muitos anos no local, vivendo com avó, mãe, pai e quatro irmãos - "sendo três menores de idade". O terceiro declarante se aposentou em 1993 e mora na mesma residência desde 1962. Logo abaixo, no fluxo do texto corrido, há o que chamo de parágrafo-nota, onde a servidora informa que os terrenos do Estradão foram cedidos ao município, sendo que uma das obrigaçóes da municipalidade era a regularizaçáo fundiária. A servidora também reitera a afirmação dada pela moradora de que "a comunidade comparecia as reunióes querendo uma resposta da municipalidade quanto ao projeto das obras que estão sendo realizadas no local". Aqui é retomada a questão da "participação popular", mas por razôes diferentes. Reforçada em ofícios e pelo texto dos defensores que moveram posteriormente a ação contra o município, 
ressaltar a participação dos moradores era importante, porque as informações náo circulavam nesses encontros, e os moradores, apesar de comparecerem, saíam deles sem nenhuma resposta. Ao mesmo tempo, um dos contra-argumentos do município era de que a populaçáo não comparecia às reunióes e por essa razáo não estava informada dos detalhes dos reassentamentos e da amplitude das obras.

Conforme as declarantes, nessas reunióes do pró-moradia se trata de assuntos diferentes daqueles que as moradoras buscavam, já que reclamam na Defensoria para obtenção de informaçóes sobre o teor das obras no entorno de suas casas. Conforme o texto do Termo, a comissão de moradores comparece às reunióes para obter informaçóes sobre as moradias e sobre a qualidade e quantidade das obras que serão realizadas. No entanto, nos encontros "é falado sobre 'dengue', 'saúde bucal' e para última reunião prometeram o comparecimento da Sr. ${ }^{\text {a Bianca }}$ (engenheira), mas quem apareceu foi a Sr. ${ }^{a}$ Sonia". Quando apareceu, a "Sr. ${ }^{a}$ Sonia" teria dado três opções à comunidade: "compra assistida, indenização ou casas que estáo sendo feitas na [nome de uma localidade dentro do Estradão] explicando que não era vantagem optar pela compra assistida ou indenizaçáo porque o valor é muito baixo, o ideal seria a casa”.

Conforme já ressaltamos neste texto, as alternativas dadas pelos agentes são na maior parte das vezes retóricas, já que são desencorajadas em face da opção mais conveniente para o município. Neste caso, as declarantes argumentam que a casa oferecida é muito pequena - " $25 \mathrm{~m}^{2}$ distribuídos em 02 andares $/ 12,5 \mathrm{~m}^{2}$ para cada andar", - ressaltando que na comunidade "há idosos, pessoas portadoras de necessidades especiais", citando como exemplo a neta do declarante que tem Síndrome de Down. Uma das declarantes diz que o irmão tem um problema nos ossos que o impede de subir e descer escadas; além disso, questiona como irão viver os oito em uma casa de $25 \mathrm{~m}^{2}$. Há um senhor que é vizinho e cuja mãe é a moradora mais antiga da comunidade: "ela é idosa e não pode subir escada, ficou sem opção, tendo a Sonia indicado a compra assistida, que ela mesma condenou e disse aos moradores que não fizessem essa opção", apontaram. Ainda no texto do Termo, ficamos sabendo que a "Sr. ${ }^{a}$ Sonia informou que a engenheira Bianca já iria começar as mediçôes nas casas dos declarantes na segunda-feira, para calcular indenizaçôes e a metragem do local, mas ela não apareceu". As declarantes dizem que a comunidade já pediu o projeto, mas o "município se omite", escreve a servidora. Uma das declarantes explica que já solicitou a Sonia "o projeto que será desenvolvido no local e para onde serão manejados”, porém teria sido informada que "isto depende da Prefeitura liberar a engenheira".

Tal como ocorre em relaçáo ao NUTH, cujos defensores e defensoras incentivavam uma forma de tratamento mais pessoalizada durante os atendimentos 
e reunióes, notamos aqui que as técnicas da prefeitura - seja da engenharia, seja da assistência social - também são chamadas pelo primeiro nome. Conforme destacado por Letícia Ferreira (2015), não é porque são documentos e porque os funcionários são parte da administração altamente burocrática que os processos são isentos de pessoalidade, seja na forma de apego, seja no cuidado, seja por interesse. Nas representaçóes produzidas sobre o Estado, a pessoalizaçáo é uma delas, já que performa e caracteriza os processos de sua formação. Conforme Souza Lima (2012:784), o ato de tutelar implica estabelecer vínculos de proximidade, e os moradores estariam imbricados em expressóes da tutela, presentes tanto na relação com a defensoria quanto na relação com os técnicos do município. Não é porque buscam uma reação e forma de resistência pela via estatal ${ }^{27}$ através de atendimento na Defensoria - que manifestaçôes do poder tutelar não estejam presentes na relação assistido-defensor mesmo e também através da pessoalização. De acordo com Souza Lima, e notamos bem essa postura nos relatos sobre as figuras de Sonia e Bianca, o tutor tem como encargo instruir, de "modo a se eternizar na posição de fonte única de autoridade na "transmissão dos conhecimentos e dos modos corretos de vivenciar o pertencimento a uma comunidade mais abrangente". Como observamos, essa comunidade abrangente aparece frequentemente sob a forma do progresso. Para estar a favor e fazer parte do progresso, é necessário aceitar os modos corretos de pertencimento indicados pelo tutor, acatar sua autoridade e seus conhecimentos. Por outro lado, quem questiona a unicidade desta autoridade é classificado como contra a obra, contra o progresso.

Como já destacamos, a produção de escombros e entulhos na realização das obras e sua manutenção no local do empreendimento foram observadas como prática da prefeitura. Como consequência dessa prática, acessos eram inviabilizados e buracos eram deixados abertos entre as casas e nas ruas do bairro. Espaços comuns das localidades - como campos, praças, largos, terrenos vazios - eram extintos, e dificilmente uma alternativa era proposta para compensar sua falta. Neste Termo, as moradoras declaram uma situação parecida. Relatam que a prefeitura, "no contexto dessas obras", "abriu um 'valáo' dentro da comunidade que está cheio d'água e virou foco de mosquitos, ratos, baratas que agora passam a 'conviver' com os moradores". Declaram que há um espaço dentro da comunidade onde caminhốes da prefeitura retiram pela noite a terra "preta" para ser vendida e, no local, despejam entulho de obra, o que "também virou foco de vetores", destaca a servidora. O declarante alega que desenvolvia um projeto social de futebol para crianças carentes no local, tendo havido uma época em que mais de 100 crianças participaram. No entanto, a "Prefeitura colocou fim ao projeto há 
cerca de dois meses, pois disseram que 'vão acabar com o campo'”. As declarantes e o declarante alegam para a servidora que acham isso um desrespeito.

Outras açóes, cujos extratos trago aqui, expóem com mais ênfase a mediação que citamos no início desta seção, oferecendo-nos elementos para a análise do sentido de justiça, das noçóes de habitação e das disputas entre o malfazer do município-réu e o benfazer da prática jurídica, ameaçada de descrédito pela população diante das "más práticas" do réu. A escolha desses extratos está em consonância com uma edição também minuciosa por parte dos defensores e das defensoras, de servidores e estagiários no que é registrado, arquivado, documentado. Conforme ressalta Vianna (2014a), a realidade dessas "aldeiasarquivo específicas" é que se apresentam como "pedaços que interessam à narrativa que por trás deles se costura: o processo criminal, a decisão judicial”. Seguimos a autora na compreensão de que o "retalhamento e o seu alinhavo a outros fragmentos - depoimentos, carimbos, protocolos - compóem as condiçóes etnográficas" que interessam neste trabalho, na medida em que são as possíveis. É, portanto, "no desenho sinuoso da produção de suas faltas e parcialidades" que devemos procurar a força desses arquivos "como constructo e como agente social, como marcas que nos indicam os mundos de onde emergem, mas também os novos mundos que fazem existir".

Para refletir sobre essas práticas, vamos percorrer os textos de duas ACPs. O primeiro é o de uma petição inicial com pedido liminar de antecipação de tutela referente a uma tradicional favela, muito próxima ao centro da cidade. Nessa localidade, em 2011, 44 comerciantes tiveram seus quiosques de trabalho demolidos irregularmente pelo município em uma ação da Secretaria Municipal de Ordem Pública conhecida na época como Choque de Ordem. ${ }^{28}$ No texto, notase fortemente o estilo da mediação ressaltada anteriormente, na produção tanto "dos fatos" como dos fundamentos jurídicos. Abrindo a exposição dos fatos - logo na página 2 do documento de 42 páginas assinado pelos cinco defensores do Núcleo na época -, temos o trecho de um samba muito popular que faz reverência à beleza da favela onde as demoliçóes ocorreram.

Logo abaixo, a ênfase é deslocada para a ação tendenciosa do município, que no mesmo dia em que a favela era "ocupada" pela Unidade de Polícia Pacificadora, "decidiu fazer valer o tão divulgado 'choque de ordem", notificando para "imediata desocupação e demolição" os 44 quiosques comerciais localizados há 20 anos em área de grande circulação na região. O prazo dado pelo município para desocupação seguida de demolição foi de 24 horas, tempo que foi chamado de "caricato" pelos defensores públicos em outros pontos da ACP (já que tampouco foi cumprido pelos demolidores). Procurado pelos moradores e comerciantes, 
o Núcleo acionou o plantão judiciário para tentar reverter a situação e obteve sucesso, já que o juiz deferiu a liminar pretendida, determinando "ao Município do Rio de Janeiro que se abstenha de praticar qualquer ato tendente à demolição ou turbação da posse dos imóveis ocupados pelos autores até nova deliberação judicial", estabelecendo como pena o pagamento de multa diária no valor de $\mathrm{R} \$ 10.000,00$ (dez mil reais) a cada um. $\mathrm{O}$ argumento desta decisão também é transcrito na ACP:

não é com truculência ou arbitrariedade que se imporá, aonde quer que seja, num Estado Democrático de Direito, a ordem que se almeja e espera. Esta há de ver respeitados os cidadáos e seus direitos, respeitado, em suma, o próprio Direito - afinal, este vigora não só em Ipanema e no Leblon, mas também (por mais estranho que isto soe ao ouvido de alguns) na [nome de diversas favelas cariocas].

Os defensores parecem perplexos ao enfatizar no texto que o "desvendamento da opacidade do 'Estado-sistema' é necessariamente feito do deslocamento de sentidos pertinente ao 'Estado-ideia' nos termos utilizados por Abrams" (Vianna, 2014b:224). Conforme as elaboraçóes do autor, o Estado como objeto especial de análise social não existe enquanto entidade real. Propondo a separação em dois objetos, tal qual descrito por Vianna e tal qual percebemos na leitura do Processo, Abrams (1988) oferece a possibilidade de refletirmos sobre o nosso próprio cativeiro ideológico, tratando isso como um objeto convincente de análise, questionando a nossa compreensão do poder institucionalizado. Seguindo o autor, fica evidente, no trecho destacado, a compreensáo universalista que os defensores usam ao citar o Estado Democrático de Direito. Conforme nos sugere Butler (2010:21), ao exigirem que o Estado vigore igual em todas as favelas e bairros da cidade, eles estão evidenciando a existência de um marco cujo rompimento revela as normas de inteligibilidade que assinalam o reconhecimento dos moradores dos bairros de maneira desigual pelo município.

De acordo com o texto da ação, "o poder de império decorrente da parcela de soberania exercida pelo Judiciário foi solenemente menosprezado pelo Munícipioréu", que tornou "tabula rasa a imposição de não turbar a posse dos comerciantes" ao demolir todos os trailers e quiosques notificados. Conforme o argumento dos defensores, esse ato era "extremamente grave", porque demonstrava o "descaso do Poder Público Municipal perante as demais autoridades constituídas, em especial o Poder Judiciário", já que esvaziava a "inevitabilidade", "decidindo, por si só", quando cumpre ou náo cumpre "os provimentos jurisdicionais". 
Conforme nos descrevem Vianna e Farias (2011), ao relatarem as táticas de atuação na busca por justiça, caracterizando o movimento de mulheres que tiveram seus filhos e familiares mortos pela polícia, a personificação do Estado que, de acordo com os relatos das mulheres com que dialogaram, "está lá comendo e bebendo" enquanto elas estão ali lutando por escuta e justiça - também está presente na atuação dos defensores que ressaltam que "o comportamento" assumido pelo Município-réu "atesta a sua séria dificuldade em reconhecer o valor da cidadania".

Atentos às práticas dos rumores como estratégia de des(habitação) utilizada pelo município, os defensores buscam penalizar a produção de "esclarecimentos inverídicos" quanto à demolição dos quiosques, divulgados pelo réu na página eletrônica da prefeitura dias após a derrubada dos imóveis. Na reportagem, a prefeitura alegava ter demolido 34 "comércios irregulares" porque os comerciantes teriam desistido da ação iniciada junto ao NUTH, acatando a proposta de "ordenamento do espaço público" sugerida pelo município. Ancorados nos Termos de Declaração dos autores da ação, os defensores buscam "desmentir" essa "barbaridade administrativa” do município-réu, já que as pessoas, quando ouvidas, "apontaram para o desconhecimento de qualquer acordo celebrado no dia 20 de junho e que permitisse a demolição dos quiosques ou trailers".

Como fundamento jurídico, a ACP refuta "o descumprimento gritante" de uma decisão judicial, usando para isso um argumento que nos provoca a refletir sobre os sentidos de justiça e de um benfazer do Estado-ideia. Segundo os defensores, quiçá o descumprimento "fosse essa postura assumida por algum partidário de ideologia anarquista", o que poderiam compreender. A "realidade sob exame", no entanto, "envolve o ilícito praticado pelo próprio Estado que adota como comportamento a aversão à decisão judicial".

A açáo é finalizada com diversos pedidos, um deles por indenização, inclusive por danos morais, em razão de disseminação de informação falsa sobre os comerciantes, que se transformaram em vítimas também pela veiculação destes esclarecimentos inverídicos. Antes, no entanto, ainda argumentando em torno do descumprimento da decisão judicial - que é uma das assinaturas do munícipioréu neste período analisado -, os defensores evocam o Estado de Direito em sua forma de tutela e, também, a confiança nas instituiçóes como patrimônios em ameaça. Os defensores, portanto, se questionam sobre "o sentimento de intenso desamparo" que pode "nutrir o cidadáo que entende ser ilícita, via de regra, a autotutela e, por isso, busca o amparo jurisdicional, obtém a tutela jurisdicional e, mesmo assim, se depara com a prepotência do Executivo?” 
Como fundamentação desta ameaça à "credibilidade das instituiçóes brasileiras", é citada uma pesquisa realizada pelo Ibope em 2009 onde "o Poder Judiciário ocupava a ilustre” posição 16 de um ranking que levava em conta 22 avaliados. A chamada "tabela do índice de confiança social" elaborada pelo instituto hierarquizava uma porção de instituiçóes e pessoas. No alto da tabela, estavam as "pessoas da família", com 90 pontos, seguidos de corpo de bombeiros, igrejas, forças armadas, meios de comunicação, amigos, presidente da República, escolas públicas, organizaçóes da sociedade civil, bancos, empresas, vizinhos, brasileiros de um modo geral, governo federal, governo da cidade onde se vive, poder judiciário/justiça (com 53 pontos), polícia, eleiçôes/sistema eleitoral, Sistema Único de Saúde, sindicatos, Congresso Nacional e partidos políticos. Após a replicação da lista divulgada pela pesquisa, argumenta-se que "não sancionar o Município-réu" representaria "dar azo a todo um processo de desvalorização e desconfiança do Judiciário”.

Em outra ação a que tivemos acesso - datada de 2011 e também referente à área central da cidade -, os agravantes eram os moradores de um imóvel privado que estava ocupado por diversas famílias havia muitos anos. O pedido era de obrigação de fazer, com antecipação da tutela, já que pleiteava a "manutenção da posse dos autores", o que evitaria o "desalijo dos requerentes". Conforme o argumento dos três defensores que assinam a ação, o indeferimento do pedido submeteria estas famílias "à degradante situação de rua, ante o desalijo forçado prestes a ocorrer". Chama atenção o argumento da tutela para conclamar o município tanto a garantir a função social da propriedade e a moradia digna como a respeitar o princípio de não remoção que consta na Lei Orgânica. Embasando esse argumento, os defensores alertam para o "recrudescimento do já inaceitável índice de população de rua", destacando a ação e influência da prefeitura no aumento desta população. Neste mesmo caminho, há o destaque de que há "aproximadamente três anos, a Municipalidade, através da Secretaria Municipal de Habitação realizou a inclusão dos dados pessoais de diversos moradores em um cadastro voltado ao oferecimento de alternativas habitacionais", no entanto, não foi fornecido "qualquer documento após referida inscrição", e os inscritos, "nas ocasiôes em que compareceram à mencionada Secretaria, não obtiveram qualquer resposta satisfatória", ou seja, até o momento "não lhe foi ofertada qualquer solução", de maneira que os moradores ameaçados de desalijo se vêm "de mãos atadas para exigir cobranças da municipalidade”.

O que vimos chamando de produção e manutençáo da precariedade nos casos de habitação e garantia à vida por parte dos governos é destacado pelos defensores (no caso do município do Rio de Janeiro) como "inatividade notória". 
Essa noção de inatividade corrobora com a forma como vimos entendendo a manutenção da vulnerabilidade por parte do município nos casos de remoçáo, mas também poderíamos pensar em outros aspectos, como na área da saúde e da segurança pública. É fundamental explicitar com qual noção de vulnerabilidade estamos dialogando, que segue a proposta de Judith Butler (2010:15) de uma nova ontologia corporal - onde ser um corpo é estar exposto às forças sociais e às exigências de sociabilidade - como modo de ampliar as reivindicaçóes sociais e políticas. Pensando a vulnerabilidade como algo que inexiste fora de sua interpretação política, ela observa as condiçóes onde é possível apreender uma vida ou um conjunto de vidas como precário. Atenta à função e ação da linguagem como campo de observação, ela distingue a precariedade em duas modalidades. Uma delas (precarity) seria a condição de existência subjetiva, onde a falta de segurança afetaria material e psicologicamente o bem-estar; trata-se de uma noção política da outra modalidade (precariousness), que remete ao risco, à instabilidade humana. Para a autora, essa diferença é o ponto de partida para repensar a política progressista, já que ela atravessa as categorias de identidade. Interessa-nos pensar com a autora na necessidade de levarmos em conta que a responsabilidade sobre os corpos vulneráveis (ou sobre as vidas precárias) deve centrar-se não só no valor da vida, ou na capacidade de sobreviver em abstrato, mas sim nas condiçóes sociais que sustentam a vida especialmente quando estas falham (2010:59).

A fim de destacar a responsabilidade por essa produção, exigindo-se nesse caso a tutela antecipada dessas famílias, os defensores constroem os autores da ação como vítimas em potencial; aqueles que "vivem em situação de dependência da boa vontade de alguns parentes ou amigos" e aqueles que "não têm com quem contar". Para os últimos, nota-se a dignidade da moradia sendo acionada pela polarizaçáo um tanto acrítica entre casa e rua, já que lhes restaria "apenas a ultrajante e inaceitável alternativa de morar nas ruas, dividindo indigno espaço com inúmeros outros que possuem como teto as marquises e viadutos desta cidade, dita por alguns, 'maravilhosa'". A fim de sensibilizar os juízes, ressalta-se a "completa situação de desamparo" dessas famílias diante da inatividade do Poder Público municipal, que teria relegado ao "ostracismo o drama social daqueles que não têm mais para onde ir”. A ação busca então, através do poder judiciário, “compelir o Município do Rio de Janeiro a sair do mais completo estado de letargia e, dessa maneira, assegurar alguma solução habitacional àqueles que foram indevidamente esquecidos". 


\section{Apontamentos finais}

Os documentos produzidos para os processos judiciais me pareceram um material relevante tanto como narrativa das diferentes nuances presentes na gestão da habitação social quanto como expressáo da dinâmica que envolve as intervençôes urbanas em áreas periféricas. Também foram produtivos como possibilidade de reencenar a relação (1) de escuta e escrita entre o servidor ou estagiário e o declarante, suas assimetrias e constrangimentos; (2) de mediação e atuação dos defensores públicos. Mostraram-nos, portanto, a tessitura dessa possibilidade de resistência e o esforço em tornar legíveis as tramas que envolvem a construçáo da opacidade das esferas governamentais nestas localidades. Ademais, todo o conteúdo das pastas e a filtragem para produção dos Processos me pareceram importantes para refletir sobre práticas de Estado e de resistência, e em como elas englobam de maneira distinta a produção de documentos.

Em meu doutorado, refleti sobre o efeito da inteligibilidade (Das, 2004) do Estado na vida dos interlocutores integrantes de redes de contestaçáo aos megaeventos - no Rio de Janeiro e também em Porto Alegre, onde fiz parte de meu trabalho de campo - irradiando sofrimento, dor, mortes através de práticas obscuras de coação, terror psicológico, promessas, controle do tempo e produção de escombros e ruínas. Usei a categoria de resiliência para explicitar uma temporalidade da resistência, que primava por uma performance não pública dos interlocutores em busca de energia, razóes, afetos, fé; que pudesse nutri-los para "seguir em frente" (Gutterres, 2016:186), com dignidade, porém em busca de que ela fosse reconhecida pela racionalidade do Estado, pelas instituições e seus funcionários. Os Processos na Defensoria Pública eram parte desse arcabouço de estratégias de sobrevivência.

Antes de finalizar, éimportante destacar que entendemos a remoção de moradias - tal qual ela é produzida pelo município - como uma das faces da (des)habitação dos pobres. A (des)habitação, tal qual vimos refletindo (Gutterres, 2016:187), foi (e segue sendo) um esforço por parte da municipalidade de desarticulação e desconstrução de redes de afeto e de convivência que são estabelecidas por meio da partilha de espaços coletivos, caminhos e percursos.

Conforme buscamos descrever ao longo do artigo, a participaçáo em um Processo envolve o sujeito em uma "aura de operação legal” (Das, 2007:241), onde os papéis recebidos são guardados em pastas com todo o cuidado, levados para a defensoria como documentos que têm vida, que têm história e que têm potencial de serem convertidos em prova judicial. Por essa importância na vida dos assistidos e pelo potencial do Processo como registro sincrônico e diacrônico da relação desses grupos com o Estado e seus ilegalismos - especialmente 
em relação à crença na coerência e na efetividade das práticas de poder da administração pública - é que apostamos nesta pesquisa como contribuição para o conhecimento já elaborado na área da antropologia dos processos de formação do Estado. É um lugar privilegiado para observar como o Estado se apresenta na vida de quem vive em áreas pobres das grandes cidades, áreas em franca reconfiguração, impactadas pelo desenvolvimento que chega, muitas vezes, através da aporia dos megaeventos e megaprojetos (Gutterres, 2014) e dos controversos planos de urbanizaçáo e moradia.

Anelise dos Santos Gutterres é pós-doutoranda em antropologia social do Museu Nacional/Universidade Federal do Rio de Janeiro. Pesquisou as práticas de remoção de moradias nas cidades sede da Copa do Mundo de 2014 e as redes de contestação formadas nesse período por grupos, entidades, militantes e movimentos sociais. Tem interesse em formação dos movimentos sociais, participação social, trajetórias de militância, ocupações do espaço urbano, conflito e crise na vida metropolitana. Atualmente, desenvolve sua pesquisa no campo da antropologia das práticas de Estado e justiça, tendo como foco habitação, políticas urbanas e gênero. Contato: adsgutterres@gmail.com. 


\section{Notas}

1. As primeiras reflexôes desta pesquisa foram apresentadas no "GT 30 - Etnografia de documentos e burocracias: desafios teórico-metodológicos da análise de práticas de poder", reunido na $30^{\circ} \mathrm{RBA}$. Nessa ocasião, recebi generosos e instigantes comentários de María Gabriela Lugones, Laura Lowenkron e Adriana Vianna que foram incorporados neste artigo. Agradeço também a leitura e as contribuiçôes de Everton Rangel, Lucas Freire, Viviane Fernandes e Letícia Carvalho de Mesquita Ferreira à versão preliminar deste texto apresentada no seminário "Formas de resoluçáo de conflitos: sentidos e usos das práticas de justiça", realizado no Museu Nacional/UFRJ em novembro de 2017. Elas foram fundamentais para a consolidação das reflexôes aqui expostas. Também gostaria de agradecer as sugestôes e críticas ao texto contidas nos pareceres encaminhados pela Comissão Editorial do Anuário Antropológico, que foram fundamentais para o fortalecimento dos argumentos e a elaboração da forma atual do artigo.

2. Núcleo especializado que atua na assistência de casos de conflito em loteamentos, conjuntos, casas e terrenos em áreas urbanas, e cujos "assistidos" enquadram-se nos parâmetros da hipossuficiência.

3. Agência ANSA. "Brasil se despede da Olimpíada e encerra era dos megaeventos", Jornal do Brasil. Disponível em: www.jb.com.br/olimpiada-2016/noticias/2016/08/22/ brasil-se-despede-da-olimpiada-e-encerra-era-dos-megaeventos. Acesso em janeiro de 2017.

4. Há diversas reportagens sobre este evento, no entanto, destaco o trabalho de Damo e Oliven (2013), que o relatam de forma crítica, destacando os alinhamentos políticos que propiciaram a vinda dos jogos ao país.

5. Desde sua criação, a equipe do NUTH foi sempre mista, e com um número maior de defensoras atuando nos casos.

6. No trabalho de campo realizado durante o doutorado, observo que a classificação "atingidos pelas obras da Copa do Mundo e das Olimpíadas" foi sendo construída como categoria política, junto aos movimentos sociais e militantes ligados à luta pela moradia digna e pelo direito à cidade, e como tática de fortalecimento do coletivo formado por aqueles que sofreram e sofrem os inconvenientes das reformas e das políticas urbanas (Gutterres, 2014:8). Era uma forma de dar visibilidade às diversas violaçôes de direitos civis sofridas por essas pessoas ao longo da preparação para os jogos. A classificação "atingidos" sempre me pareceu fortemente inspirada no Movimento dos Atingidos por Barragens (MAB), no entanto, nunca presenciei declaração ou manifestação que afirmasse esse vínculo durante meu período em campo.

7. Conforme o vocabulário jurídico disponível no site do Tribunal de Justiça do Distrito Federal e dos Territórios e do Conselho Nacional de Justiça, uma Ação Civil Pública "visa proteger a coletividade, responsabilizando o infrator por danos causados ao meio ambiente, ao consumidor, à ordem urbanística, a bens e direitos de valor artístico, 
estético, histórico, turístico e paisagístico, a qualquer outro interesse, bem como a direito difuso ou coletivo. Poderá ser proposta pelo Ministério Público, pela Defensoria, pela União, pelos Estados e pelos Municípios, por autarquias, empresas públicas, fundações, sociedades de economia mista e associações interessadas, pré-constituídas há pelo menos um ano". Disponível em: https://www.tjdft.jus.br/acesso-rapido/informacoes/ vocabulario-juridico/entendendo-o-judiciario/acao-civil-publicaCNJ e http://www.cnj. jus.br/noticias/cnj/81222-cnj-servico-entenda-a-diferenca-entre-acao-popular-e-acaocivil-publica. Acesso em janeiro de 2018.

8. Diferenciarei a palavra "processo", que alude ao tempo transcorrido, do "Processo" como redução de "processo judicial", usando neste último caso a letra maiúscula.

9. Aqui destaco o texto de Alexandre Mendes (2014), ex-defensor do NUTH, que tem escrito sobre esse ciclo do Núcleo. Também é interessante consultar a coletânea organizada por ele e Giuseppe Cocco, onde constrangimentos e desafios deste período são descritos sob o ponto de vista de integrantes da equipe que trabalhou no NUTH. Para caracterizar o modelo de trabalho do NUTH na Defensoria Pública pré-2011, os autores utilizam a noção de "instituiçóes do comum" (2016:15) a partir de uma reflexão de Bruno Cava que as caracterizaria como "uma rede de institucionalidades nem estatais e nem privadas", instituiçôes que priorizam a "transversalidade", e a "gestão compartilhada" adotando mecanismos de participação social na sua atuação.

10. Retomo aqui o caminho escolhido por Lopes (2016:12) para a compreensão das práticas e formas de poder em sua tese de doutorado. Partindo de uma desnaturalização de aspectos em torno do poder, o autor o descreve como algo que se "realiza em ato, conduzido e operado pelos sujeitos de forma contextual". Para que isso seja viável, é necessário observar as operaçôes cotidianas que produzem o poder, "ficando atento aos acionamentos possíveis e performados entre aqueles que são seus condutores e entre aqueles que devem ser conduzidos".

11. Como ressaltam Mendes e Cocco (2016:17), uma prática administrativa e de atuação e operação do direito que enxerga o direito à cidade como uma "coprodução do urbano" só é possível a partir do desenvolvimento de conhecimentos e linguagens comuns.

12. Uso a expressão "do lado de lá" porque não sou funcionária ou integrante do corpo de operadores da justiça. Como participei ativamente do apoio aos moradores e moradoras da Providência, frequentando os atendimentos na Defensoria ao lado deles e delas, me coloquei, até o princípio desta pesquisa, apesar de não ser assistida, no lugar de quem está "do lado de cá" do balcão. Quando passei a realizar a investigação dentro do Núcleo, essa condição foi aos poucos se transformando, e frequentemente eu era confundida com as "doutoras" no contexto - mulheres brancas com formação universitária. Essa situação me instigou a participar de espaços, na militância e no âmbito acadêmico, que buscassem refletir sobre as marcas e os efeitos da branquitude do judiciário (e da academia) para a populaçáo pobre e/ou náo branca, tema de extrema relevância, mas que, no entanto, não abordarei neste artigo. 
13. É importante destacar a conjuntura do país no período de captação dos megaeventos. Conforme destacam Damo e Oliven (2013:34-37), o Brasil era o $8^{\circ}$ PIB do mundo em 2009; com taxa de desemprego baixa e um aumento de $54 \%$ no número de trabalhadores com ocupação formal desde a década anterior. São destacados também os avanços nas áreas sociais, com a implementação e ampliação da política de habitação, de cotas raciais e étnicas nas universidades públicas, e a instituição do Bolsa Família.

14. Como já ressaltado em minha tese de doutorado, a partir da noção de governamentalidade de Michel Foucault (2008), essa forma de atuaçáo foi observada em periferias, regióes centrais e favelas das cidades sede durante todo o período de preparação para a realizaçấo da Copa do Mundo no país.

15. Era comum, e muitas vezes incentivado pela defensoria, que o coletivo que entrasse com a ação também formasse uma comissão de moradores para acompanhar as obras e se proteger de tentativas de negociação individual por parte do município, revezando-se na participação em reunióes e demandas ligadas à ação.

16. Uma declaração enfatizando que a situação econômica de determinada pessoa não lhe permite pagar os custos do Processo e os honorários advocatícios sem prejuízo do sustento próprio ou da família. Não é imprescindível que seja configurado estado de miserabilidade do assistido para que ele se enquadre nessa classificação.

17. São as mulheres que ocupam com mais frequência o lugar de recolhimento e guarda de tais documentos. Nos períodos em que estive acompanhando o trabalho do Núcleo, presenciei diversas vezes os relatos de que elas tinham saído mais cedo do trabalho para comparecer na Defensoria, cujo horário de atendimento regular era até às $15 \mathrm{~h}$. Eram elas que avaliavam os papéis que poderiam constar como prova, que pressionavam por respostas (ligando ou comparecendo à sede), que os levavam até o Núcleo para que fossem copiados, na esperança de que pudessem contribuir para o andamento do Processo e um desfecho favorável.

18. "Uma luta por dignidade" foi como descrevi, em minha tese, o percurso das interlocutoras da pesquisa diante de práticas regulares do Estado em seus locais de moradia. Essa luta não se restringe a uma reivindicação por moradia digna, mas a engloba. Mencionando frequentemente "a forma como a prefeitura tem feito", as mulheres a associavam a violaçōes diversas nos seus direitos civis. Denunciar essa forma era como um motor da luta. Entre as violaçóes descritas, figuram principalmente as informaçóes falsas dadas pelos funcionários que não as tratam como "gente"; a demolição de moradias antes do prazo estipulado e sem respeito à legislação; as ocupações, do exército e da polícia, na favela em que viviam, que invadia as casas e controlava de maneira truculenta a circulação dos moradores e moradoras nos acessos e espaços comuns.

19. Destaco o trabalho de Fix (2001), que descreve o oferecimento de "alternativas" durante as obras realizadas pela Operação Urbana Consorciada Água Espraiada, em São Paulo. Nesse caso, as "alternativas" também foram oferecidas como paliativo para remoção dos moradores. 
20. Pelo que venho notando, aquelas famílias que permaneceram, geralmente, estavam assistidas pela defensoria.

21. É uma das etapas do processo de extinção de uma casa. No entanto, o mais comum nas favelas que tiveram casas descaracterizadas é que elas permaneçam descaracterizadas, ou seja, sem demolição completa. Realizada por agentes do município ligados à SMH e à Secretaria Municipal de Ordem Pública (SEOP), a descaracterização consiste em retirar esquadrias e marcos de porta, destruindo com marretas a abertura onde ficavam as portas e janelas. Também são feitos buracos grandes no teto de todos os cômodos, de modo que o local não possa mais abrigar o interior da chuva ou da luz. $\mathrm{O}$ objetivo é evitar a reocupação para fins de moradia.

22. É preciso destacar o vigoroso trabalho de Vera Telles (2010), que retomou para nós a gestão dos ilegalismos presente na obra de Foucault para refletir sobre os ilegalismos que costuram as tramas e situaçóes contemporâneas dos centros e periferias das cidades. São importantes também as coletâneas organizadas em torno do tema, que aprofundam o debate sobre o legal e o ilegal em diferentes locais e contextos (Azaïs, Kessler \& Telles, 2012; Telles \& Cabanes, 2006). Trabalhando especificamente com mercado informal, sublinho também as pesquisas de Telles e Hirata (2010), no contexto da cidade de Sáo Paulo. Na cidade do Rio de Janeiro, destaco o trabalho de Birman, Fernandes e Pierobon (2014) sobre as tramas entre o ilegal e o legal em uma ocupação de moradia localizada em torno da Central do Brasil.

23. Sobre essa prática de extorsão de dinheiro, ver o relatório realizado pela Justiça Global em 2011 sobre os crimes de maio de 2006 em Sáo Paulo, sobre os quais também reflete Feltran em sua tese de doutorado (2011).

24. Era uma prática das secretarias e órgãos da prefeitura não tornar públicos os projetos urbanos implementados nas favelas.

25. Conforme disponibilizado no site da Caixa Econômica Federal, o recurso para esse programa vem do Fundo de Garantia do Tempo de Serviço (FGTS), com contrapartida do solicitante - estados, municípios, Distrito Federal e empresas públicas. Ele é destinado a famílias com renda mensal de até $R \$ 1.395,00$ e "conta com a experiência técnica da Caixa para auxiliar na análise e no acompanhamento dos projetos". Disponível em: http://www.caixa.gov.br/poder-publico/programas-uniao/habitacao/pro-moradia/ Paginas/default.aspx. Acesso em: 25/06/2016.

26. Declaraçôes como esta eram tão comuns quanto a prática do município em não promover um debate participativo, conforme as diretrizes da Lei Federal no 10.257, de 10 de julho de 2001, conhecida como Estatuto da Cidade.

27. Os moradores não consideram o acompanhamento dado pela defensoria como a principal ou exclusiva forma de resistência. Muitos dos integrantes das comissóes participavam de movimentos sociais ou, em alguns casos, a própria comissão se transformava em um embriâo de alguma forma associativa ou de reivindicação popular. As iniciativas de transformação do cenário de remoçôes eram realizadas de maneira 
concomitante a partir de diferentes formas de resistência. Como já ressaltado neste artigo, os grupos que participavam das açóes e as viam como forma de resistência eram uma minoria.

28. Como ressaltam Laignier e Fortes (2010:53; 67), a criação da secretaria foi uma das primeiras medidas de Eduardo Paes ao assumir a prefeitura do Rio de Janeiro em 2009. A Operação Choque de Ordem foi posta em prática pela secretaria neste mesmo ano, sob a justificativa de cessar a "desordem urbana", considerada pelos governantes da época como "o grande catalisador da sensação de insegurança pública e a geradora das condições propiciadoras à prática de crimes", já que, segundo o texto divulgado no site, "uma coisa leva a outra". Apostando que essa sensação de insegurança bania "as pessoas e os bons princípios das ruas", contribuindo para a "degeneração e a reduçáo das atividades econômicas", a operação foi apoiada por boa parte da imprensa. Acompanhando as manchetes e capas dos 100 primeiros dias do governo de Eduardo Paes, os autores mostram como a operação era veiculada no jornal $O$ Globo, que noticiava as ações repressivas de recolhimento de menores de idade e moradores de rua, apreensão de mercadorias, repressão à "publicidade irregular" e, principalmente, as repressóes ocorridas no trânsito e nas favelas $(2010: 53$; 67), que foi o foco da operaçáo e onde ela teve maior impacto. Notícia disponível em: http://www.rio.rj.gov.br/web/guest/ exibeconteudo?article-id=87137. Acesso em janeiro de 2018.

\section{Referências}

ABRAMS, Philip. 1988. "Notes on the difficulty of studying the state". Journal of Historical Sociology, 1(1):58-89.

AZAÏS, Christian; KESSLER, Gabriel \& TELLES, Vera da Silva (org.). 2012. Ilegalismos, cidade e política. Belo Horizonte: Fino Traço.

BIRMAN, Patrícia; FERNANDES, Adriana \& PIEROBON, Camila. 2014. "Um emaranhado de casos: tráfico de drogas, estado e precariedade em moradias populares". Revista Mana, 20(3):431-460.

BUTLER, Judith. 2010. Marcos de guerra. Madrid: Paidós.

CASTILHO, Sérgio Ricardo; SOUZA LIMA, Antonio Carlos de \& TEIXEIRA, Carla Costa. 2014. "Etnografando burocratas, elites, e corporaçôes: a pesquisa entre estratos sociais hierarquicamente superiores em sociedades contemporâneas". In: Sérgio Ricardo Castilho; Antonio Carlos de Souza Lima \& Carla Costa Teixeira (org.). Antropologia das práticas de poder: reflexóes etnográficas entre burocratas, elites e corporaçôes. Rio de Janeiro: Contracapa, Faperj. pp. 7-32 
COMITÊ POPULAR RIO DA COPA E OLIMPÍADAS. 2011. Megaeventos e violação dos direitos humanos no Rio de Janeiro: dossiê do Comitê Popular da Copa e Olimpíadas do Rio de Janeiro. Disponível em: http://www.apublica.org/wp-content/uploads/2012/09/ dossic3aa-megaeventos-e-violac3a7c3b5es-dos-direitos-humanos-no-rio-de-janeiro.pdf. Acesso em: 03/04/2017.

- 2012. Megaeventos e violação dos direitos humanos no Rio de Janeiro: dossiê do Comitê Popular da Copa e Olimpiadas do Rio de Janeiro. 2a ed. Disponível em: http://www.portalpopulardacopa.org.br/index.php?option=com k2\&view=item\&id=198:dossi\%C3\%AA-nacional-de-viola\%C3\%A7\%C3\%B5es-dedireitos-humanos. Acesso em: 03/04/2017.

DAMO, Arlei \& OLIVEN, Ruben G. 2013. "O Brasil no horizonte dos megaeventos esportivos de 2014 e 2016: sua cara, seus sócios e seus negócios”. Horizontes Antropológicos, 19(40):19-63.

DAS, Veena. 2004. “The signature of the state”. In: Veena Das \& Deborah Poole (org.). Anthropology in the margins of the State. Santa Fe: School of American Research Press. pp. 225-252.

2007. Life and words: violence and the descent into the ordinary. California: University of California Press Berkeley and Los Angeles.

FAULHABER, Lucas. 2012. Rio Maravilha: práticas, projetos políticos e intervenção no território no início do século XX. Dissertação de mestrado, Universidade Federal do Rio de Janeiro.

FELTRAN, Gabriel de Santis. 2011. Fronteiras da tensão: politica e violência nas periferias de São Paulo. São Paulo: Unesp; CEM; Cebrap.

FERNANDES, Adriana. 2013. Escuta ocupação: arte do contornamento, viração e precariedade no Rio de Janeiro. Tese de doutorado, Universidade do Estado do Rio de Janeiro.

FERREIRA, Letícia Carvalho de Mesquita. 2013. "Pesquisar e participar da formulação de uma causa pública: notas etnográficas sobre o desaparecimento de pessoas no Brasil". Revista Campos, 14(1-2):195-216.

2015. Pessoas desaparecidas. uma etnografia para muitas ausências. Rio de Janeiro: Editora UFRJ.

FIX, Mariana. 2001. Parceiros da exclusão: duas histórias da construção de uma "nova cidade” em São Paulo: Faria Lima e Água Espraiada. São Paulo: Boitempo.

FONSECA, Claudia. 1997. "Ser mulher, mãe e pobre". In: Mary Del Priore (org.). História das mulheres no Brasil. São Paulo: Contexto. pp. 510-553. 
FONSECA, Claudia. 2004. "A certeza que pariu a dúvida: paternidade e DNA". Estudos Feministas, 12(2):13-34.

FOUCAULT, Michel. 2004. Vigiar e punir: nascimento da prisão. Petrópolis, Vozes.

FOUCAULT, Michel. 2008. O Nascimento da Biopolítica. São Paulo, Martins Fontes.

FREIRE, Lucas de Magalhães. 2015. A máquina da cidadania: uma etnografia sobre a requalificação civil de pessoas transexuais. Dissertação de mestrado, Museu Nacional, Universidade Federal do Rio de Janeiro.

GUTTERRES, Anelise dos Santos. 2014. A resiliência enquanto experiência de dignidade: antropologia das práticas políticas em um cotidiano de lutas e contestaçôes junto a moradoras ameaçadas de remoção nas cidades sede da Copa do Mundo 2014 (Porto Alegre, RS e Rio de Janeiro, RJ). Tese de doutorado, Universidade Federal do Rio Grande do Sul.

. 2016. "O rumor e o terror na construção de territórios de vulnerabilidade na zona portuária do Rio de Janeiro". Revista Mana, 22 (1):179-209.

HIRATA, Daniel. 2010. Sobreviver na adversidade: entre o mercado e a vida. Tese de doutorado, Universidade de São Paulo.

LAIGNIER, Pablo \& FORTES, Rafael. 2010. "A criminalização da pobreza sob o signo do 'Choque de Ordem': uma análise dos primeiros cem dias do governo Eduardo Paes a partir das capas de O Globo". Comunicação \& Sociedade, 31(53):53-78.

LOPES, Paulo Victor Leite. 2016. "Homens autores de violência doméstica": relaçóes de gênero, formas cotidianas de governo e processos de formação de Estado. Tese de doutorado, Museu Nacional, Universidade Federal do Rio de Janeiro.

LOWENKRON, Laura \& FERREIRA, Letícia. 2014. "Anthropological perspectives on documents: ethnographic dialogues on the trail of police papers". Vibrant - Virtual Brazilian Anthropology, 11(2):75-111.

LUGONES, Maria Gabriela. 2009. Obrando en autos, obrando en vidas: formas e fórmulas de "proteção judicial" dos tribunais prisionais de menores de Córdoba, Argentina, no comę̧o do século XXI. Tese de doutorado, Museu Nacional, Universidade Federal do Rio de Janeiro.

MACHADO DA SILVA, Luiz Antonio \& FIGUEIREDO, Ademir. 2015. "Urbanização x remoçáo". In: Luiz Antonio Machado da Silva. Fazendo a cidade: trabalho, moradia $e$ vida local entre as camadas populares urbanas. Rio de Janeiro: Mórula. Coleção Engrenagens Urbanas. pp. 70-83. 
MAGALHÃES, Alexandre. 2013. Transformaçôes no "problema favela" e a reatualização da "remoção" no Rio de Janeiro. Tese de doutorado, Universidade do Estado do Rio de Janeiro.

MENDES, Alexandre. 2014. "A nova luta da Vila Autódromo e dos moradores que resistem à remoção: reconstruir a Defensoria Pública e sua autonomia". Revista Lugar Comum, (42):77-84.

MENDES, Alexandre \& COCCO, Giuseppe. 2016. A resistência à remoção de favelas no Rio de Janeiro - instituiçôes do comum e resistências urbanas: a história do Núcleo de Terras e Habitação e a luta contra a remoção. Rio de Janeiro: Revan.

PEIRANO, Mariza. 1986. "Sem lenço, sem documento, reflexôes sobre cidadania no Brasil”. Revista Sociedade e Estado, 1(jun):49-63.

RILES, Annelise. 2006. "Introduction: in response". In: . (ed.). Documents: artifacts of modern knowledge. Ann Arbor: The University of Michigan Press. pp. 1-38.

SCHUCH, Patrice. 2009. Práticas de justiça: antropologia dos modos de governo da infância e juventude no contexto pós-ECA. Porto Alegre: Editora da UFRGS.

SOUZA LIMA, Antonio Carlos de. 1995. Um grande cerco de paz: poder tutelar, indianidade e formação do Estado no Brasil. Petrópolis: Vozes.

. 2002. "Sobre gestar e gerir a desigualdade: pontos de investigação e diálogo". In: _______ (org.). Gestar e gerir: estudos para uma antropologia da administração pública no Brasil. Rio de Janeiro: Relume-Dumará. pp. 11-21.

TELLES, Vera. 2010. "Nas dobras do legal e do ilegal: Ilegalismos e jogos de poder nas tramas da cidade". DILEMAS: Revista de Estudos de Conflito e Controle Social, Vol. 2 No 5-6 - JUL/AGO/SET-OUT/NOV/DEZ: pp. 97-126.

TELLES, Vera da Silva e CABANES, Robert (org.). 2006. Nas tramas da cidade: trajetórias urbanas e seus territórios. São Paulo: Associação Editorial Humanitas.

TELLES, Vera e HIRATA, Daniel. 2010. "Ilegalismos e jogos de poder em São Paulo". Tempo Social, revista de sociologia da USP, Vol. 22, No 2: pp. 39-59.

VIANNA, Adriana de Resende B. 1999. O mal que se adivinha: polícia e menoridade no Rio de Janeiro (1910-1920). Rio de Janeiro: Arquivo Nacional.

. 2014a. "Etnografando documentos: uma antropóloga em meio a processos judiciais". In: Sérgio Castilho, Antonio Carlos de Souza Lima \& Carla Costa Teixeira (org.). Antropologia das práticas de poder: reflexôes etnográficas entre burocratas, elites e corporaçôes. Rio de Janeiro: Contra Capa/Faperj. pp. 43-70. 
VIANNA, Adriana de Resende B. 2014b. "Violência, estado e gênero: consideraçóes sobre corpos e corpus entrecruzados". In: Antonio Carlos de Souza Lima \& Virginia García-Acosta (org.). Margens da violência: subsidios ao estudo do problema da violência nos contextos mexicano e brasileiro. Brasília: ABA. pp. 209-236.

VIANNA, Adriana \& FARIAS, Juliana. 2011. "A guerra das mães: dor e política em situaçôes de violência institucional”. Cadernos Pagu (37):79-116. 


\section{Resumo}

Este artigo é resultado de uma pesquisa nos documentos de um Núcleo especializado da Defensoria Pública do estado do Rio de Janeiro, instituição que foi ativa na defesa de grupos de moradores em territórios ameaçados de remoção durante o período de preparação para os megaeventos no município do Rio de Janeiro. O objetivo é, a partir da análise de estratos de Ações Civis Públicas, refletir sobre a existência de uma razão governamental no tratamento desses territórios, compreendendo aqui o Estado em seus múltiplos aspectos, em suas múltiplas "assinaturas", como propõe Veena Das (2007). Apostamos que a pesquisa nos documentos produzidos para os processos judiciais traga um material relevante para reflexóes sobre as dimensóes do conflito na gestáo da habitação social e na dinâmica que envolve as reformas urbanas em áreas periféricas, apontando-nos também para a tessitura de possibilidades de resistência - nesse caso, pela via estatal - e o esforço em tornar legíveis as tramas que envolvem a construção da opacidade por esferas governamentais nestas localidades.

Palavras-chave: Estado, remoção, conflito, urbanização, Defensoria Pública.
This article is the result of a documentary research in a specialized nucleus of the Public Defender's Office of the State of Rio de Janeiro, an institution that actively defended groups of residents in territories threatened of removal during the preparation for megaevents in the city of Rio de Janeiro. The objective is to analyze the existence of a governmental reason in the treatment of these territories, understanding the State in its multiple aspects, in its multiple 'signatures', as proposed by Veena Das (2007). The documentary research in the judicial processes will bring relevant material for reflections on the dimensions of conflict in the management of social housing and the urban interventions in peripheral areas, pointing to the different possibilities of resistance - in this case, through the state - and the inhabitants' effort to reveal the practices that involve the construction of the opacity of the governmental spheres in these localities.

Keywords: State, displacement, conflict, urbanization, Public Defense. 